\title{
KONTRIBUSI MOTIVASI BELAJAR DAN HASIL BELAJARWIRAUSAHA DENGAN KESIAPAN BERWIRAUSAHA SISWA KELAS XII SMK NEGERI 1 BATAM
}

\section{MOTIVATION AND LEARNING OUTCOMES ENTREPRENEURSHIP CONTRIBUTION WITH READINESS ENTREPRENEURS OF XII GRADE STUDENTS SMK NEGERI 1 BATAM}

\author{
Nispida Yeni ${ }^{1}$, Suryo Hartanto ${ }^{2}$ \\ ${ }^{1}$ SMK Negeri 1 Batam, ${ }^{2}$ Universitas Riau Kepulauan \\ suryo@fkip.unrika.ac.id
}

\begin{abstract}
Abstrak
Kesiapan berwirausaha siswa SMK N I Batam sangat rendah dibuktikandengan rendahnyajumlah lulusanyang berwirausaha. Tujuan penelitian ini adalah untuk mengungkapkan Hubungan motivasi berwirausaha dan hasil belajar kewirausahaan dengan kesiapan berwirausaha siswa kelas XII SMK N I Batam. Penelitian ini adalah penelitian korelasional. Populasi dalam penelitian ini adalah siswa kelas XII SMK N I Batam yang berjumlah 282 orang dan sampel sebanyak 159, sampel dipilih acak dengan metode sampling menggunakan nomogram Harry King. Instumen penelitian ini menggunakan angket dan nilai hasil belajar kewirausahaan. Angket yang digunakan telah di Uji validitas dan reliabilitas. Berdasarkan hasil penelitian, terdapat hubungan motivasi berwirausaha dengan kesiapan berwirausaha $r=0.533$ dan kontribusi sebesar $28.4 \%$, terdapat hubungan hasil belajar kewirausahaan dengan kesiapan berwirausaha $r=0.594$ dan kontribusi sebesar 35.2\%, terdapat hubungan motivasi berwirausaha dan hasil belajar kewirausahaan secara simultan dengan kesiapan berwirausaha $r=0,678$ dan kontribusi sebesar 46\%. Berdasarkan hasil penelitian dapat disimpulkan bahwa motivasi berwirausaha dan hasil belajar kewirausaha adalah dua faktor yang berhubungan dengan kesiapan berwirausaha siswa SMK N I Batam.
\end{abstract}

Kata kunci: Motivasi, Hasil belajar, Kesiapan berwirausaha

\begin{abstract}
Readiness of student entrepreneurship SMK N I Batam is very low with indication of low graduates who entrepreneurship. The purpose of the research is to reveal the relationship of entrepreneurship motivation and entrepreneurship learning outcomes with readiness entrepreneurship of XII gradesof SMK N I Batam. This research is correlational. The population were the students of XII grades of SMK N I Batam which amounted to 282 people and 159 samples, the sample was chosen randomly, using the nomogram of Harry King. The research instrument use a questionnaires and entrepreneurial learning outcomes. Questionnaire used has been tested for validity and reliability. Based on the research, there is a correlation between entrepreneurship motivation with entrepreneurship readiness $r=0.533$ and contribution of $28.4 \%$, there is relationship of entrepreneurship learning result with entrepreneurship readiness $r=0.594$ and contribution of $35.2 \%$, there is relationship of entrepreneurship motivation and entrepreneurship learning outcomes simultaneously with entrepreneurial readiness $r=0.678$ and contribution of $46 \%$. Based on the research, can be concluded that the motivation of entrepreneurship and entrepreneurship learning outcomes are two factors related to the readiness of entrepreneurship students of SMK N I Batam
\end{abstract}

Keywords: Motivation, Learning Outcomes, Readiness of entrepreneurship 



\section{PENDAHULUAN}

Lapangan kerja yang tersedia semakin sempit, tetapi angkatan kerja yang menginginkan pekerjaan semakin besar, tingginya persaingan dan sulitnya mendapatkan pekerjaan, menjadi tantangan tersendiri untuk dunia pendidikan, dalam hal ini adalah pendidikan kejuruan. Pendidikan kejuruan yang dimaksudkan antara lain adalah Sekolah Menengah Kejuruan (SMK). SMK dalam proses pendidikanya memiliki spesifikasi yang berbeda dibanding dengan sekolah menengah yang lain.(Hartanto, Lubis, \& Rizal, 2017). Pendidikan kejuruan merupakan program pendidikan yang diselenggarakan secara langsung dan dikaitkan dengan persiapan individu dalam mengembangkan karir yang dibutuhkan, selain jenjang pendidikan sarjana atau pendidikan kejuruan yang sederajat.Salah satu tujuan pendidikan SMK adalah untuk mewujudkan manusia yang berkualitas yang mempunyai kesiapan dan kemampuan dalam menghadapi berbagai persoalan kehidupannya, antara lain mendapatkan pekerjaan dengan membuka usaha sendiri atau berwirausaha.Widodo (2005). Wirausaha adalah usaha (sembarang jenis usaha) yang dilaksanakan dengan sifat-sifat kewiraan, yaitu berani, percaya diri, siap menanggung resiko, dan terutama sekali harus berorientasi masa depan dengan memanfaatkan dan mengelola peluang usaha (bisnis) yang ada. Hisrich-Peters (2004), Entrepreneur is the process of creating something different with value by devoting the necessary time effort, assuming the accompanying financial, psychic and social risk, and receiving the resulting rewards of moterary and personal satisfaction and independence. Siswa lulusan SMK telah disiapkan untuk mencari kerja secara mandiri atau membuka lapangan kerja. Eman Suparno (Dit. PSMK. 2006), secara psikologis lulusan SMK lebih percaya diri dengan kemampuan yang diperoleh selama masa pendidikan. SMK juga merupakan sistem pendidikan yang job oriented (berorientasi pada pekerjaan) dimana lulusannya siap kerja dan siap membuka lapangan kerja.SMK yang dituntut memiliki hardskills pada bidang keahlian yang dimiliki dan diharapkan dapat mengisi lapangan pekerjaan setelah lulus sekolah atau dapat menciptakan lapangan pekerjaan sendiri dari skill yang dimiliki, (Hartanto, 2015).Berdasarkan observasi sekolah dan alumni, hanya terdpat 1,85\% tamatan SMK Negeri 1 Batam yang berwirausaha dan masih ada yang menganggur khususnya kerja yang tidak permanen di industri/kontrak. Sedangkan tamatan 
lainnya ada yang bekerja menjadi karyawan di perusahaan di Batam, luar negeri dan instansi pemerintahan seperti Polisi, TNI, Bea Cukai, Dinas Pemerintah Daerah.

Tabel 1. Data Alumni bulan September 2015

\begin{tabular}{llr}
\hline No. & Pekerjaan & \multicolumn{1}{c}{ Jumlah } \\
\hline 1. & Karyawan PMA & 1126 orang \\
2. & Karyawan BUMN & 186 orang \\
3. & Karyawan PMDN & 314 orang \\
4. & PNS & 476 orang \\
5. & Kepolisian & 124 orang \\
6. & TNI & 56 orang \\
7. & Belum bekerja & 312 orang \\
8. & Wirausaha & 50 orang \\
9. & Tidak bisa ditelusuri & 155 orang \\
& Total & 2699 orang \\
\hline
\end{tabular}

Sumber: Data Alumni SMKN 1 Batam Tahun 2015

Berdasarkan data di atas kurangnya sikap wirausaha pada siswa lulusan SMK Negeri 1, diindikasikan sebagai berikut:kurang percaya diri yakni suka mencontek dan meniru pekerjaan orang lain; tidak berani menanggung resiko yakni tidak suka diberi tugas yang banyak dan menantang; kurang kreatif dengan ketergantungan pada guru yang tinggi; kurangnya kemampuan manajerial diindikasikan dengan sedikitnya siswa yang aktif di organisasi sekolah, kurangnya kemampuan berkomunikasi diindikasikan dengan jarangnya siswa yang bertanya saat proses pembelajaran dan tidak sedikit siswa yang tidak saling mengenal terutama dengan siswa pada program keahlian yang berbeda. Indikasi tersebut diatas sangat bertolak belakang dengang kondisi yang diharapkan. Astamoen (2005) bahwa: Sikap dan profil yang sebaiknya dimiliki oleh seorang wirausaha adalah kreatif, inovatif, banyak ide dan gagasan dalam segala hal, mencari dan mengisi peluang, dan orientasi pada konsumen dalam membuat produk dan menjual barang atau jasa.

Dalam berwirausaha memerlukan kesiapan pengetahuan, sikap mental dan kemampuan berwirausaha.Astamoen (2005),menjadi entrepreneur tidak dapat disuruh, kecuali melalui kesadaran, keinginan, panggilan hidup, hasrat dan motivasi kuat disertai belajar, kerja keras dan berpikir keras dari individunya sendiri dengan segala risiko dan keberhasilan untuk dan karena diri sendiri.Alma (2004) watak yang perludimilikiwirausahaadalah: 1). Keyakinan, ketidaktergantungan, individualitas dan optimism, 2). Kebutuhan akan prestasi, berorientasi laba, ketekunan dan ketabahan, tekad kerja keras, mempunyai dorongan kuat, energik dan inisiatif, 3). Kemampuan mengambil 
risiko, suka pada tantangan, 4). Bertingkahlaku sebagai pemimpin, dapat bergaul dengan orang lain, menanggapi saran-saran dan kritik, 4).Inovatif dan kreatif serta fleksibel, 5). Pandangan ke depan, perspektif

Banyak faktor yang dapat mempengaruhi terhadap kesiapan berwirausaha seseorang, baik yang menyangkut dalam dirinya (faktor internal), maupun yang berhubungan dengan lingkungan sekitar (faktor eksternal). Faktor internal meliputi: minat, bakat, motivasi, kemandirian, pengetahuan dan keterampilan, pengalaman kerja, dan lain-lain. Sedangkan faktor eksternal meliputi: lingkungan masyarakat, lingkungan keluarga, lingkungan sekolah, pendidikan, dan lain-lain. Shane (2007) menyatakan bahwa hal yang tak kalah penting dalam menumbuhkan jiwa kewirausahaan adalah motivasi, sebagian besar entrepreneur dimotivasi oleh keinginan untuk menentukan nasibnya sendiri.

Belajar mengajar merupakan proses yang berkelanjutan untuk mencapai sebuah perubahan yang harus dilalui oleh siswa dalam pendidikan sekolah. Sardiman (2003), belajar merupakan suatu usaha untuk menguasai ilmu pengetahuan menuju terbentuknya kepribadian seutuhnya.Kewirausahaan dalam pendidikan SMK merupakan salah satu mata pelajaran dalam proses belajar mengajar yang diberikan kepada siswa sebagai wujud implementasi untuk menyiapkan lulusan SMK yang mandiri. Materi pembelajaran harus sesuai dengan kebutuhan lapangan kerja agar lulusan SMK dapat bekerja pada bidang keahlian yang sesuai dengan yang diperoleh di bangku sekolah, (Rukun, Huda, \& Hartanto, 2015).Soemanto (2002) Pendidikan kewirausahaan berusaha untuk menjawab tantangan mewujudkan manusia yang berkualitas guna menjadikan manusia bukan hanya mampu mencari pekerjaan, melainkan untuk mengembangkan sumberdaya manusia yang mampu menciptakan pekerjaan bagi dirinya sendiri, atau bahkan mampu menyediakan lapangan kerja bagi oranglain. Indriyanto (2004:6), 1). Kewirausahaan berisi “body of knowledge” yang utuh dan nyata (distinctive), 2). Kewirausahaan memiliki dua konsep, yaitu posisi “venturestart up” dan “venture growth”, 3). Kewirausahaan merupakan disiplin ilmu yang memiliki objek tersendiri, 4). Kewirausahaan merupakan alat untuk menciptakan pemerataan berusaha dan pemerataan pendapatan atau kesejahteraan rakyat yang adil dan makmur. Berdasarkan pemaparan yang di atas maka tujuan penelitian ini adalah untuk mengetahui kontribusi yang dapat diberikan dari motivasi dalam berwira usaha dan hasil 
belajar pada pelajaran wirausaha terhadap kesiapan berwirausaha siswa SMK Negeri 1 Batam.

\section{METODOLOGI}

Jenis penelitian ini adalah kuantitatif dengan teknik korelasional, penelitian ini bertujuan untuk mengungkapkan gejala-gejala serta hubungan antar variabel yang hasil analisisnya disajikan dalam bentuk deskripsi dengan menggunakan angka-angka statistik.Populasi dalam penelitian ini adalah siswa kelas XII, pada enam program studi keahlian di SMK Negeri 1 Batam berjumlah 282 siswa, sampel penelitian berjumlah 159. Teknik pengumpulan data dengan menggunakan instrumen angket untuk motivasi berwirausaha dan kesiapan berwiraussaha, sedangkan untuk hasil belajar kewirausahaan menggunakan data hasil belajar yang diperoleh siswa dalam belajar kewirausahaan mulai dari semester satu sampai semester lima dengan mengambil nilai rata-rata. Instrumen angket telah dilakukan uji analisis instrumen yang dinyatakan valid dan reliabel.

\section{HASIL DAN PEMBAHASAN}

Berdasarkan hasil penelitian, dijabarkan diskripsi kuantitatif dan hasil uji hipotesis sebagai berikut:

Kesiapan Berwirausaha

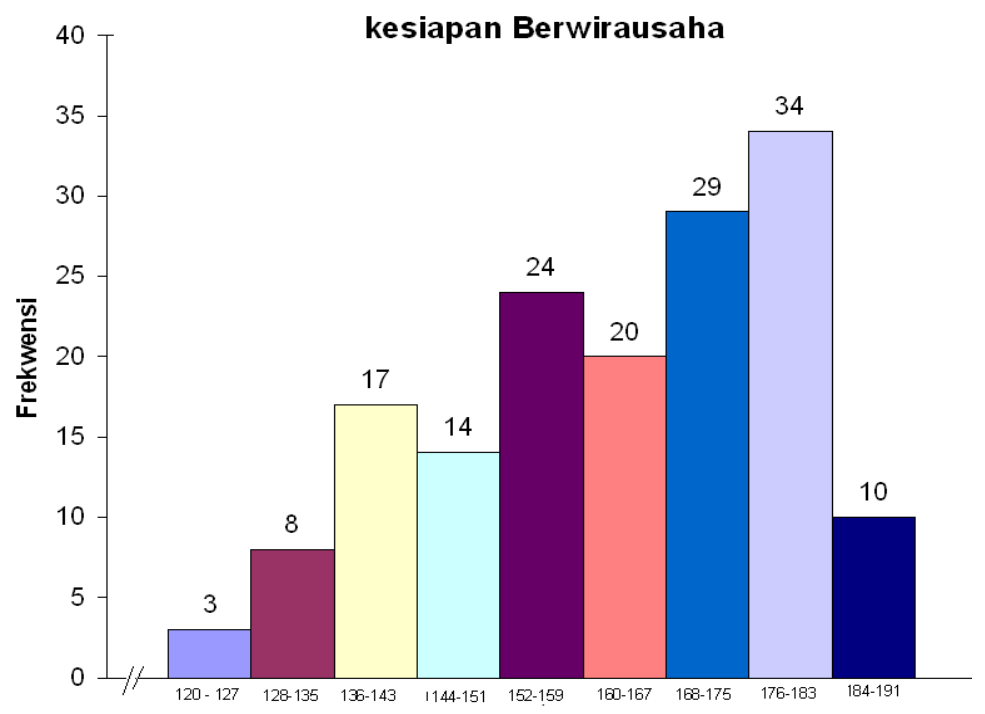

Gambar 1. Histogram Kesiapan Berwirausaha 
Motivasi berwirausaha

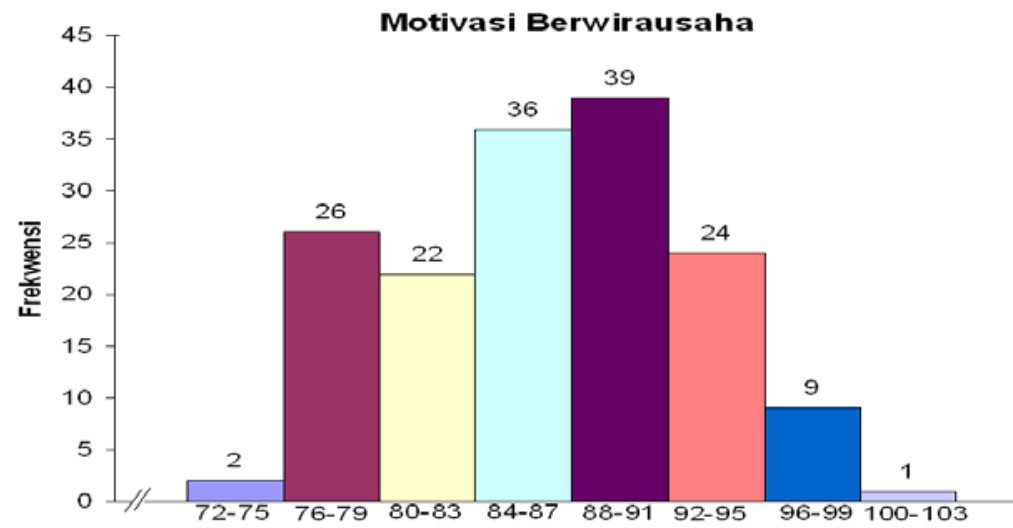

Gambar 2. Histogram Motivasi Berwirausaha

Hasil belajar Kewirausahaan

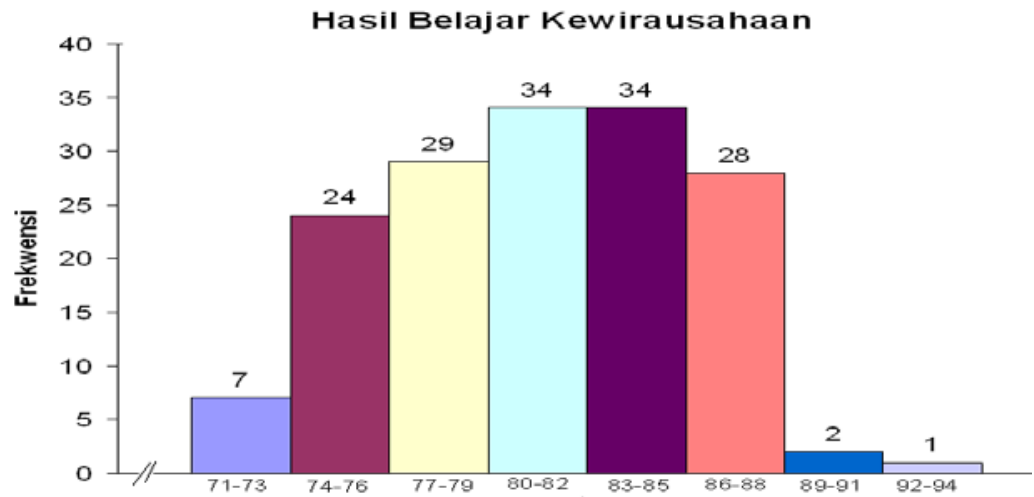

Gambar 3. Histogram Hasil Belajar Kewirausahaan

Berdasarkan perhitungan hipotesis penelitian, dijabarkan pada tabel berikut.

Tabel 2. Rangkuman Hasil Analisis Regresi Sederhana

\begin{tabular}{lllll}
\hline Model & $R$ & $R$ Square & $\begin{array}{l}\text { Adjusted } R \\
\text { Square }\end{array}$ & Std. Error of the Estimate \\
\hline 1 & $.533^{\mathrm{a}}$ & .284 & .279 & 14.153 \\
\hline 2 & $.594^{\mathrm{a}}$ & .352 & .348 & 13.459 \\
\hline 3 & $.678^{\mathrm{a}}$ & .460 & .453 & 12.333 \\
\hline
\end{tabular}

Hasil analisis regresi variabel motivasi berwirausaha dengan hasil belajar berwirausaha menunjukkan bahwa motivasi berwirausaha mempunyai hubungan positif dengan kesiapan berwirausaha. Koefisien korelasi $\left(\mathrm{r}_{\mathrm{yx} 1}\right)$ sebesar 0.533 dan koefisien determinasi $\mathrm{R}_{\text {square }}$ 
yang antara motivasi berwirausaha dengan kesiapan berwirausaha sebesar 0.284. Kontribusi yang diberikan variabel motivasi berwirausaha dengan kesiapan berwirausaha adalah sebesar 28.4\%.Berdasarkan hasil analisis antara motivasi berwirausaha (X1) dengan kesiapan berwirausaha siswa kelas XII SMKN 1 Batam menunjukkan tingkat hubungan sedang berdasarkan interpretasi korelasi Sugiyono (2006:257). Dengan besar sumbangan 28,4\% terhadap kesiapan berwirausaha, artinya setiap perubahan terhadap kesiapan berwirausaha siswa (Y) terdapat unsur motivasi berwirausaha di dalamnya.

Hasil belajar Kewirausahaan dengan kesiapan berwirausaha mempunyai hubungan positif dengan kesiapan berwirausaha siswa kelas XII SMK N I Batam. Hal ini terlihat pada koofisien korelasinya $\left(\mathrm{ryx}_{2}\right)$ sebesar 0.594 , koefisiendeterminasi $\left(\mathrm{R}_{\text {square }}\right)$ sebesar 0.352. Kontribusi yang diberikan variable hasil belajar Kewirausahaan dengan kesiapan berwirausaha sebesar 35.2\%. Berdasarkan hasil analisis antara hasil belajar Kewirausahan dengan kesiapan berwirausaha siswa SMKN 1 Batam menunjukkan tingkat hubungan sedang berdasarkan interpretasi korelasi Sugiyono (2006:257). Dengan besar sumbangan 35,2\% artinya setiap perubahan terhadap kesiapan berwirausaha siswa (Y) terdapat unsur motivasi berwirausaha di dalamnya.

Analisis regresi berganda variabel motivasi berwirausaha dan hasil belajar kewirausahaan dengan kesiapan berwirausaha, secara simultan mempunyai hubungan dengan tingkat hubungan yang kuat dengan kesiapan berwirausaha (Y), koofisien korelasi berganda $\left(\mathrm{r}_{\mathrm{x} 1, \mathrm{x} 2}\right)$ sebesar 0,678 , koefisien determinasi berganda $\left(\mathrm{R}_{\text {square }}\right)$ sebesar 0.460 dengan signifikan $\alpha=0,05$. Hal ini menunjukan bahwa motivasi berwirausaha $\left(\mathrm{X}_{1}\right)$ dan hasil belajar kewirausahaan $\left(\mathrm{X}_{2}\right)$ secara simultan terdapat hubungan yang signifikan dan memberikan kontribusi terhadap kesiapan berwirausaha siswa sebesar $46 \%$.

Untuk melihat keberartian persamaan regresi berganda dilakukan uji $\mathrm{F}$ terhadap variabel motivasi berwirausaha dan hasil belajar Kewirausahaan dengan kesiapan berwirausaha (Y). Bertujuan untuk mengetahui apakah variabel independen (X1, X2) secara bersama-sama berhubungan secara signifikan terhadap variabel dependen (Y). 
Tabel 3. Uji F

\begin{tabular}{|c|c|c|c|c|c|c|}
\hline Model & & $\begin{array}{l}\text { Sum of } \\
\text { Squares }\end{array}$ & Df & $\begin{array}{l}\text { Mean } \\
\text { Square }\end{array}$ & $\mathrm{F}$ & Sig. \\
\hline \multirow[t]{3}{*}{1} & Regression & 20184.920 & 2 & 10092.460 & 66.353 & $.000^{\mathrm{a}}$ \\
\hline & Residual & 23727.998 & 156 & 152.103 & & \\
\hline & Total & 43912.918 & 158 & & & \\
\hline
\end{tabular}

Berdasarkan Tabel 3 memperlihatkan nilai statistik signifikansi pada uji F sebesar 0,000 kecil dari alpha 0,05 atau pada taraf kepercayaan 95\%. Untuk uji dua pihak, dengan derajat kebebasan df2 (n-k-l) atau 159-2-1 = 156 maka $F_{\text {tabel }}$ didapat sebesar 3,08. Dari data tersebut dapat disimpulkan nilai $\quad F_{\text {hitung }}>F_{\text {tabel }}$ maka Ho ditolak dan Ha diterima artinya bahwa terdapat hubungan signifikan antara motivasi berwirausaha dan hasil belajar kewirausahaan secara simultan dengan kesiapan berwirausaha siswa kelas XII SMKN 1 Batam. Bentuk persamaan Regresi Berganda $\quad$ adalah $\hat{\mathbf{Y}}=\mathbf{- 5 8 . 5 3 3}+\mathbf{0 . 9 9 0} \mathbf{X}_{\mathbf{1}}+$ $1.669 \mathrm{X}_{2}$.

\section{KESIMPULAN}

Berdasarkan hasil penelitian didapatkan kesimpulan sebagai berikut: 1). Terdapat hubungan motivasi berwirausaha dengan kesiapan berwirausaha siswa kelas XII SMK N I Batam dengan nilai kontribusi sebesar 28.4\%, 2). Terdapat hubungan hasil belajar Kewirausahaan dengan kesiapan berwirausaha dengan nilai kontribusi sebesar 35.2\%, 3). Terdapat hubungan motivasi berwirausaha dan hasil belajar Kewirausahaan secara simultan dengan kesiapan berwirausaha, dengan nilai kontribusi sebesar 46\%.

\section{REFERENSI}

Alma, B. (2004). Kewirausahaan. Bandung: Alfabeta.

Astamoen, P.M. (2005). Entrepreneurship dalam Persepktif Kondisi Bangsa Indonesia. Bandung: Alfabeta.

Dit. PSMK. (2006). Sekolah Menengah Kejuruan. Jakarta: Depdiknas.

Hartanto, S. (2015). Komparasi Pemahaman Geometris Karyawan Lulusan SMK Dan SMA Terhadap Proses Machining CNC Di PT.Tomoe Valve Batam, 4(2), 34-42. Retrieved from http://journal.unrika.ac.id/index.php/jurnalphythagoras/issue/view/20 
Hartanto, S., Lubis, S., \& Rizal, F. (2017). Need And Analysis Of Soft Skills For Students Of The Mechanical Engineering Department Of Vocational, 12(30), 156-159. https://doi.org/http://dx.doi.org/10.21660/2017.30.TVET017

Hisrich. Peters. M (2004). Entrepreneur. $4^{\text {th }}$ edition. Singapore. Mc Graw Hill Companies, Inc

Indriyanto, B. (2004). Model Layanan Profesional Pemelajaran Kewirausahaan: Sekolah Menengah Kejuruan. Jakarta: Balitbang Puskur Depdiknas.

Rukun, K., Huda, A., \& Hartanto, S. (2015). Designing Interactive Tutorial Compact Disc For Computer Network 23-26. https://doi.org/http://dx.doi.org/10.11113/jt.v77.6682

Shane, S.,Locke, E. A, Collins, C. J (2007). Entrepreneurial Motivation Human Resource Management Review. Elsevier Sciense Inc.

Soemanto, W. (2002). Pendidikan Wiraswasta. Jakarta: Bumi Aksara.

Sugiyono. (2006). Metode Penelitian Pendidikan: Pendekatan Kuantitatif, Kualitatif, dan $R \& D$. Bandung: Alfabeta.

Widodo, W. (2005). Jendela Cakrawala Kewirausahaan. Bogor: IPB Press. 